
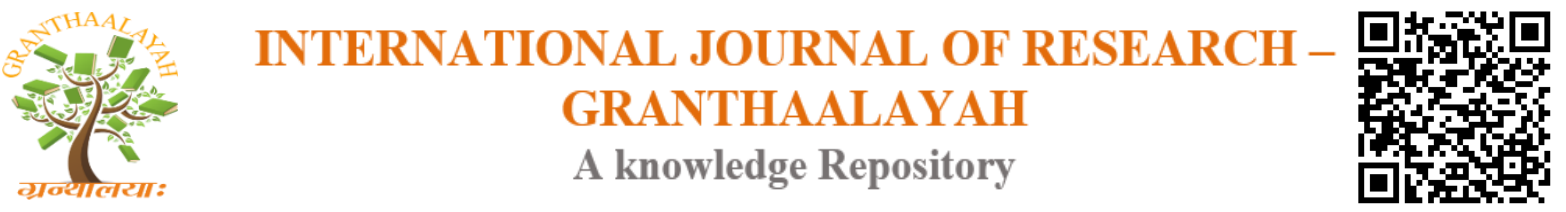

Social

\title{
DEVELOPMENT AND VALIDATION OF E-CONTENT ON HISTORY SUBJECT (THE BEGINNING OF MODERN AGE) OF IX STANDARD STUDENTS
}

\author{
J. Muthukumari ${ }^{1}$, Dr. N. Ramakrishnan ${ }^{2}$ \\ ${ }^{1}$ Ph.D. Research scholar (Part-Time) Department of Educational Technology Tamil Nadu \\ Teachers Education University Chennai - 600 097, India \\ ${ }^{2}$ Professor and head Department of Educational Technology Tamil Nadu Teachers Education \\ University Chennai - 600 097, India
}

\begin{abstract}
Technology in the information revolution has provided many unique benefits to instructional programs. Normally in the growth of technology applications in education, we are moving towards a Virtual Reality where the distance between the teacher and the taught is nil. The possibility of such virtual reality can be made by generating good e-Contents and accessible by all. E-contents are basically a package that satisfies the conditions like i.e. minimization of the distance, cost effectiveness, user-friendliness and adaptability to local conditions. The purpose of this study is to develop and validate e-content package on the unit "the Beginning of Modern Age" of IX standard student's history syllabus of Tamil Nadu government.
\end{abstract}

Keywords: Development; Validation; E-Content; History.

Cite This Article: J. Muthukumari, and Dr. N. Ramakrishnan. (2017). "DEVELOPMENT AND VALIDATION OF E-CONTENT ON HISTORY SUBJECT (THE BEGINNING OF MODERN AGE) OF IX STANDARD STUDENTS." International Journal of Research - Granthaalayah, 5(9:SE), 46-50. https://doi.org/10.5281/zenodo.1004563.

\section{Introduction}

In the field of education there is no restriction on students to learn the basic concepts of reading and writing. The modern age gives more chances to the students to face the world with all that they have learned at school level. The new and modern education system involves modern information and communication technologies in the teaching-learning process for teaching the $21^{\text {st }}$ Century students. Technology is a powerful tool for problem-solving, conceptual development and critical thinking. 'E-content' is one of the recent techniques in the educational technology. In this e-content way of instruction teaching is learner centric. The expansion for econtent is electronic content. E-content is a product of e-learning. The products bring solutions to facilitate quick and efficient development in education. To maintain standard or quality in education one should make use of e-content in the teaching-learning process. 


\section{Development and Validation of E-Content Package}

The objective of the present study is to develop and validate an e-content package on the unit the Beginning of Modern Age. In order to prepare and validate the e-content package the investigator followed a number of steps, which are given under the following headings.

\section{Identification of History Unit}

In order to develop an e-content package, the investigator selected unit "the Beginning of Modern Age" in the syllabus of IX standard history subject after consultation with history lecturers and post graduate history teachers working in higher secondary schools.

\section{Identification of Teaching Points}

The investigator identified the teaching points for the unit the Beginning of Modern Age in the IX standard history subject of Tamil Nadu State Board syllabus following English Medium.

\section{Review By Experts}

The investigator presented the teaching points to the history lecturers and post graduate history teachers working in higher secondary schools and they were appraised about the purpose of the experiment. After this, the history teachers verified and reviewed the teaching points. This ensures content validity and face validity of the items.

Table 1: Development of E-Content Package

\begin{tabular}{|l|l|}
\hline CONTENT & E-CONTENT \\
\hline Introduction & Audio/ Video/Images \\
\hline The Age of Reason & Audio/ Video/Images \\
\hline Renaissance & Audio/ Video/Images \\
\hline Renaissance in Italy & Audio/ Video \\
\hline The Renaissance Movement & Audio/ Video \\
\hline Art & Audio/ Video/Images \\
\hline Sculpture and Paintings & Audio/ Video/Images \\
\hline Music & Audio/ Video/Images \\
\hline Rise of Humanism & Audio/ Video \\
\hline Humanism & Audio/ Video \\
\hline Science & Audio/ Video/Images \\
\hline Printing and Mariner's Compass & Audio/ Video/Images \\
\hline Results of the Renaissance & Audio/ Video \\
\hline Reformation & Audio/ Video/Images \\
\hline Martin Luther & Audio/ Video/Images \\
\hline Imperial Diet & Audio/ Images \\
\hline Protestants & Audio/ Images \\
\hline Counter Reformation & Audio/ Images \\
\hline Ignatius Loyola and the Society of Jesus & Audio/ Video/Images \\
\hline The Council of Trent & Audio/ Images \\
\hline
\end{tabular}




\begin{tabular}{|l|l|}
\hline The Inquisition and Index & Audio/ Images \\
\hline Geographical Discoveries (Knowledge about Earth) & Audio \\
\hline Prince Henry & Audio/ Video/Images \\
\hline The Fall of Constantinople & Audio/ Video \\
\hline Marco Polo & Audio/ Video/Images \\
\hline Bartholomeo Diaz & Audio/ Video/Images \\
\hline Vasco das Gama & Audio/ Video/Images \\
\hline Christopher Columbus & Audio/ Video/Images \\
\hline Fernando Cortez & Audio/Video/Images \\
\hline Ferdinand Magellan & Audio/Video/Images \\
\hline Amerigo Vespucci \& Martin Wald Muller & Audio/ Video/Images \\
\hline
\end{tabular}

\section{Development of Script for E-Content Package}

After consultation with experts, the investigator prepared the script for the e-content package. The script was prepared not missing even a single teaching point for the study of unit "the Beginning of Modern Age". Based on the script, the investigator developed the e-content package for the subject unit. The developed script was given to history teachers to check the accuracy of content of the script.

The following steps were used to develop the scripts

- Knowing the subject: Gathered all the materials, met people, went to libraries red newspaper, reviews on relevant documents were done. Materials were collected widely.

- Arranging the sentence packets as logically as possible going from familiar to unfamiliar ending with appropriate conclusions.

- Rewriting and necessary finishing was done to give the final product unity, proportion and continuity.

- The drafting of the full length scripts with a complete list of visual illustrations and accompanying sound, voice and music.

The shooting script was made by breaking down the screen play into shots by the investigator and taking care of the details of the technical aspects. The shooting script was the blue print of the whole e-content. It gave the complete picture of the final schedule. It had all the details of camera dimension, lighting suggestion, music and sound. This is how the script was transferred into e-content form.

\section{Developing Visual Content}

After the scripts were written, the contents of the selected topics were transferred into the form of visuals. Visuals were made to use for illustrative talk, When Audio instruction presented with the use of visuals, it clarifies the concept and leads to the meaningful association of ideas. As far as the visual components were concerned, visuals were made. Rough drafts of simple and uncluttered layouts were prepared. Then these sketches were given to the artist. Then e-content with logical sequence were shot from the visual. 
Table 2: Schematic Presentation of Development of E-Content Package

\begin{tabular}{|l|l|}
\hline For the development of e-content package & Purpose \\
\hline $\begin{array}{l}\text { History lecturers and post graduate history } \\
\text { teachers working in higher secondary schools }\end{array}$ & $\begin{array}{l}\text { For getting ideas regarding construction of e- } \\
\text { content package and identifying teaching } \\
\text { points of the Beginning of Modern Age. }\end{array}$ \\
\hline $\begin{array}{l}\text { Four IX standard students from Vivekananda } \\
\text { Matriculation Higher Secondary School, } \\
\text { Uthukottai, Tiruvallur District, TamilNadu. }\end{array}$ & For trying out the e-content package \\
\hline Two Experts & For validating e-content package \\
\hline
\end{tabular}

\section{Try Out of E-Content Package}

The prepared e-content package was played back to four IX standard students from Vivekananda Matriculation Higher Secondary School, Uthukottai, Tiruvallur District, TamilNadu. The econtent package ran for 2 hours 47 minutes.

\section{Validation of E-Content Package}

In order to validate the e-content package, the investigator gave the e-content package to two experts. Then two experts gave their feedback. Based on their feedback modifications were done in the package. The modified e-content package was again reviewed by the experts. This approved the final form of the e-content package.

\section{Conclusion}

In this present study the investigator has developed and validated e-content package on the unit "the Beginning of Modern Age" in the IX standard history subject of Tamil Nadu State Board syllabus following English Medium.

\section{References}

[1] Aggarwal, J. C. (1996). Teaching of History. New Delhi, Vikas Publishing House Pvt. Ltd.

[2] Anandan, K., \& Gopal B. V. (Sep 2011). Information and Communication Technology in Classroom Instruction. Edutracks, v11 n1, p9-10.

[3] Arora, K. L. (2006). Teaching of History. Ludhiana, Tandon Publications, p1-2.

[4] Best W. John. \& Kahn V. James. (2014). Research in Education. Delhi, PHI Learning Private Limited. Chennai.

[5] Dinesh Kumar., \& Amit Singh, (Jan 2013). Computer Technology as an Interactive Teaching System a New Trend in Education. Edutracks, v12 n5, p15-18.

[6] Durga Padhiyarm, (2014). Educational Technology. New Delhi, Cyber Tech Publication, p1.

[7] Elizabeth Joshua., \& Ancy George, (Jan-Mar 2014). Interactive Multimedia: The Pinnacle of Education. Journal of Educational Research and Extension, ISSN 0973-6190, v51 (1), p22-26.

[8] Golden, S. A. R. (2016). Rural Students'attitude towards English as Medium of Instruction in Higher Education-An Analysis. International Journal of Research, 3, 1-10.

[9] Golden, S. A. R. (2017). Attitude of Students and Teachers towards E-Learning-An Analysis. Recent Research in Social Science \& Humanities, 1, 5-10.

[10] Golden, S. A. R., \& Regi, S. B. (2013). Mobile commerce in modern business era. International Journal of Current Research and Academic Review, 1(4), 96-102. 
[11] Gupta, S. P. (1969). Statistical Methods. New Delhi, Sultan Chand \& Sons.

[12] Henry E. Garrett, (2014). Statistics in Psychology and Education. Delhi, Surjeet Publications.

[13] Kothari, C. R., \& Gaurav Garg, (2014). Research Methodology, Methods and Techniques. New Delhi, New Age International Publishers.

[14] Lizeron Eremias., \& Subash, N. (Jan 2013). E-Content Development: A milestone in the dynamic progress of e-learning. International Journal of Teacher Educational Research (IJTER), v2 n1, ISSN: 2319-4642.

[15] Narayan Dash Biranchi, (2003). Teaching of History. Hyderabad, Neelkamal Publications Pvt. Ltd.

[16] Regi, S. B., \& Golden, S. A. R. (2014). A Descriptive Study on the Role of Consumer Psychology and Behaviour in Product Purchasing. Indian Streams Research Journal, 3 (12), 1, 6.

[17] Regi, S. B., \& Golden, S. A. R. (2014). A Study on Educational Loan Availed By Students in Trichy City. Journal of International Academic Research for Multidisciplinary (Jiarm), 2 (1).

[18] Text Book for Standard Nine, (2013). TamilNadu Textbook Corporation.

[19] Thakur, K. R. (2010). Educational Development and Technology. New Delhi, Saurabh Publishing House.

[20] Thiyagu, K., \& Muthuchamy, I. (Oct-Dec 2012). Effectiveness of E-Content in Learning Mathematics among Secondary Teacher Trainees. Research and Reflections on Education, v10 n04, p-9-12. 